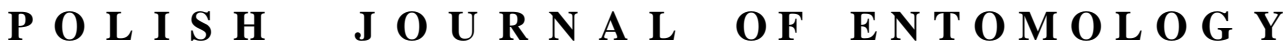

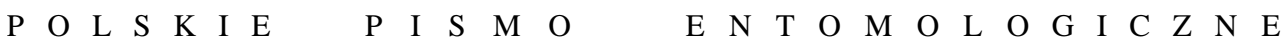

VOL. 84: $233-248$

Lublin

30 December 2015

DOI: $10.1515 /$ pjen-2015-0020

\section{Chemical and physiological changes caused by aphids feeding on their host plants*}

\author{
ElŻBIETA CICHOCKA ${ }^{1}$, WOJCIECH GOSZCZYŃSKI ${ }^{2}$, MAGDALENA LUBIARZ $^{1}$ \\ ${ }^{1}$ Department of Environmental Protection and Landscape Preservation, The John Paul II \\ Catholic University of Lublin, Konstantynów 1h, 20-708 Lublin, Poland, \\ e-mails: elzbieta.cichocka@kul.pl, lubiarz@kul.pl \\ ${ }^{2}$ Department for Natural Foundations of Landscape Architecture, The John Paul II Catholic \\ University of Lublin, Konstantynów 1h, 20-708 Lublin, Poland, \\ e-mail: wojciech.goszczynski@kul.pl
}

\begin{abstract}
We present significant information about damage caused to plants by the feeding of piercing-sucking insects, based on the example of aphids. Research concerning the impact of aphids on their host plants was already being carried out in the 1950s in the $20^{\text {th }}$ century, but it is still being undertaken as it is very important. Aphid feeding causes deformation of plant tissues, disorders in plant metabolism and changes in the amount of various compounds in plant tissues. Plant viruses are transmitted in aphid saliva.
\end{abstract}

KEY WORDS: aphid damage, aphid feeding, biochemistry and physiology of plant responses to aphids, piercing-sucking insects.

\section{INTRODUCTION}

Damage caused by insects with chewing mouthparts are often visible to the naked eye. These include biting out holes in plants, leaf mining, punctures in twigs, trunks, etc. The feeding of insects with piercing-sucking mouthparts is a highly complicated and often hidden process. This paper presents a review of the most important data concerning the

\footnotetext{
* The paper is dedicated to Prof. Wacław WOJCIECHOWSKI in recognition of his great contribution to the taxonomy and faunistics of Hemiptera.
} 
negative effects of aphids feeding on plants and some other representatives of the Sternorrhyncha suborder.

\section{THE FEEDING MECHANISM OF APHIDS}

Aphids feed on phloem sap, which they draw using piercing-sucking mouthparts. The mouthparts of aphids have a quite complex structure (see MCLEAN \& KINSEY 1984). The main components comprising this organ include the labium, two pairs of mandibular and maxillary stylets, the salivary pump, the cibarial pump and the taste organ. During food extraction the mandibular stylets adjoin one another closely, and the grooves that run along their sides form two canals - a food canal and a smaller salivary one. The food is extracted through the food canal and simultaneously, saliva is injected into the plant through the salivary canal. During the insertion of the stylets into the plant, the labium decreases in size, touching the surface of plant (TJALLINGII 1978). Feeding begins with the secretion of a drop of saliva onto the surface of the plant. Saliva is also secreted along the pathway of the stylets to ease their movements inside the plant. Most often the phloem sap is passively transferred into the mouthparts. However, sometimes the cibarial pump takes part in the active extraction and transfer of food into the stomach. With the aid of the salivary pump, saliva produced by four pairs of salivary glands is injected into the plant tissues (POLLARD 1973). Aphids produce two types of saliva - gel and watery (DAY \& IRZYKIEWICZ 1954, WILL et al. 2007, WILL et al. 2012). Gel saliva forms a sheath around the stylets within which they can move freely (MILES 1987). But the lubrication function of the sheath is questioned by WILL \& VILCINSKAS (2015). According to MitTLER (1957) aphid saliva creates a canal transporting liquid food into the body of the insect. Aphid gel saliva and the salivary sheath protect the stylets from damage. This salivary sheath remains in the plant as a remnant of stylet penetration. It also deactivates the protective substances secreted by the attacked plant (MILES 1987, WiLL et al. 2012, WILL \& VILCINSKAS 2015). Both saliva fractions mix in the salivary canal (MLES 1967, 1999). In insects we can observe adaptation of the salivary enzymes into the ingredients of the extracted food. The invariable components of Hemiptera saliva are hydrolases and polyphenol oxidase (NUORTEVA 1962).

AL-MousAwI et al. (1983) observed saliva lining the pathways of the stylets and detected streaky darkening of epidermal, bundle sheath and phloem cells. The walls of these cells were partially hydrolysed: nuclei, chloroplasts and mitochondria, as well as starch grains became degraded, whereas the protoplasts of the damaged cells, in the form of a bubbly mass, were transferred into the extracellular space. CICHOCKA (1984) observed darkening of the palisade and spongy parenchyma, damage to cell membranes and 
epidermal cells on both leaf sides in the galls of Pemphigus bursarius (LINNAEUs, 1758) on the petioles of cottonwood.

The stylet pathways and the sites of sap extraction are different. The aphid stylets are inserted into the plant intercellularly, through cells, or even through trichomes (LESZCZYŃSKI 1996). POLLARD (1973) distinguished three groups in Sternorrhyncha: piercing intercellularly into the phloem (e.g. Aphididae), piercing intracellularly into the parenchyma (e.g. Lachnidae), and reaching the phloem intracellularly (e.g. Coccidae).

Aphids penetrate plant tissues intercellularly, but on their way they puncture the surrounding cells and then reach the phloem (POLLARD 1973, BOTHA \& EVERT 1978, TJALLINGII \& HogEN EsCH 1993, HogENHOUT \& Bos 2011). Thanks to these punctures aphids can detect sieve tubes inside the plants. HEWER et al. $(2010,2011)$ showed that sucrose and $\mathrm{pH}$ are indicators of sieve tube recognition. Aphids normally feed on phloem sap, but if food resources are insufficient they will also feed on the parenchyma (POLLARD 1973). Sometimes aphids extract fluids from the xylem and bundle sheaths (SORIN 1966). They feed from the xylem in order to replenish their water supply (MONTLOR \& TJALLINGII 1989). The manner in which aphids pierce plant tissues depends not only on the species (or even the biotype), but also on the stage of development, the host plant species and the type of tissue or organ (LOWE 1967, POLLARD 1973, CichOCKA 1980). Aphids are also capable of piercing stomata (SORIN 1960, 1966, POLLARD 1971). Stylet insertion into the plant lasts between a few minutes and a few hours depending on the aphid species and host plant (CichOCKA 1980). Aphid phloem feeding can last for up to 15 days (MONTLOR \& TJALLINGII 1989).

\section{SUBSTANCES INTRODUCED INTO PLANTS WITH APHID SALIVA AND THE DISORDERS THEY CAUSE}

Phloem sap extraction, nutrient deprivation, the introduction of toxic saliva, and polluting plants with honeydew are examples of the direct harmfulness of piercing-sucking arthropods. On the other hand, plant virus transmission, which causes viral diseases, is indirectly harmful.

Aphid saliva has been found to contain mainly proteins and phospholipids, but also other compounds (Miles 1968, 1999, MADHUSUdHAN \& MiLES 1998, CherquI \& TJALLINGII 2000, RAO et al. 2013). The saliva introduces into the plant enzymes that hydrolyse cell walls, partially digest nutrients, and detoxify plant allelochemicals in the food and in the surrounding tissues (MITTLER 1957). Aphid saliva also contains effector proteins that can be delivered into the host during feeding. These proteins are required for aphid feeding and they can modulate host cell processes (CHERQUI \& TJALLINGII 2000, 
TJALLINGII 2006, HOGENHOUT \& BOS 2011, ElZINGA \& JANDER 2013, RODRIGUEZ \& BOS 2013, JAOUANNET et al. 2014). RODRIGUEZ \& BOS (2013) suggest that aphid effectors interact with host plant proteins in order to suppress defences, for example. RAO et al. (2013) identified twelve proteins in the saliva of Sitobion avenae (FABRICIUS, 1775) and seven in that of Metopolophium dirhodum (WALKER, 1849). NiCHOLSON \& PUTERKA (2014) identified 32 salivary proteins in four Schizaphis graminum (RONDANI, 1852) biotypes, while CAROLAN et al. (2009) identified nine such proteins in Acyrthosiphon pisum (HARRIS, 1776). Aphid watery saliva contains sugars (FEIR \& BECK 1961) and amino acids (SCHÄLLER 1963). NUORTEVA (1962) also detected gibberellic acid, whereas LINDNER et al. (1962) found phosphates. The watery saliva also contains proteins that prevent calciuminduced sieve tube occlusion (WILL et al. 2007, WILL et al. 2009, WILL \& VAN BEL 2008, GIORDANENGO et al. 2010). The gel saliva of many aphid species contain the sheath protein (SHP), which is a major structural protein of the salivary sheath and is required for its hardening (WILL \& VILCINSKAS 2015). WILL \& VILCINSKAS (2015) also suggest that the salivary sheath prevents the influx of calcium from the apoplast.

The salivary sheath has been found to contain polyphenol oxidase, which is said to accumulate indole-3-acetic acid in neighbouring cells. This acid can cause gall formation, which can also be enabled by the presence of gibberellins and cytokinins, as well as free amino acids in the saliva (CiCHOCKA 2001). Both saliva fractions (watery and gel) have been found to contain numerous enzymes. These include polyphenol oxidase, peroxidase, polygalacturonase, cellulases, esterases, proteases, $\alpha$-amylases, phosphatases, phosphorylases, $\beta$-glycosidase and pectin-esterases (LESZCZYŃSKI 1996, MADHUSUDHAN \& MiLES 1998, URBAŃSKA et al. 1998). Pectin polygalacturonase can cause hydrolysis of pectins in cell walls. Under the influence of aphid saliva, cell membranes are permeable not only to water, but also to sugars and low molecular weight proteins (СicHOCKA 2001). URBAŃSKA et al. (1994) found that the saliva of Sitobion avenae contains active peroxidases, polyphenol oxidase and $\beta$-glycosidases. These enzymes hydrolyse middle lamellas, cell walls, and even entire protoplasts, enabling the stylets to penetrate plant tissues (URBAŃSKA \& NIRAZ 1990).

\section{WHAT SUBSTANCES PRESENT IN A PLANT CAUSE IT TO BE ACCEPTABLE AS A HOST?}

Whether a plant is acceptable as a host depends on basic metabolites such as monosaccharides, sucrose, peptides, as well as proteins and free amino acids (CIEPIELA 1990, SEMPRUCH 2010). Nitrogen can be found in plants in low concentrations of only $1-3 \%$. Nonetheless, this element, being a constituent of amino acids, proteins, nucleotides, 
nucleic acids, plant pigments, vitamins and other compounds, is important for the growth and development of herbivores (CIEPIELA \& SEMPRUCH 1993). To aphids the most important nutrients are nitrogen compounds such as free amino acids, low molecular weight amides, peptides, nucleotides and proteins (MORALES et al. 2001, SEMPRUCH 2010, CZERNIEWICZ et al. 2011). The main feeding stimulants for cereal aphids are sucrose, fructose, and the amino acids leucine, isoleucine and histidine. Plant sap extracted from the cutting mouthparts of aphids was found to contain 5-10\% monosaccharides, as well as $0.2 \%$ amino acids and amides (AUCLAIR 1963). Only a fraction of sugars is utilized by aphids, the majority being excreted in the form of honeydew (AUCLAIR 1976). Phloem sap in sieve tubes contains a lower concentration of protein substances than cell sap in other tissues (CIEPIELA et al. 1991). Therefore, in order to satisfy their demand for protein compounds, aphids need to extract large amounts of sap. Aphids need about 20 amino acids in order to develop properly. Sugars are also important to these insects and the main feeding stimulator is sucrose (SRIVASTAVA \& AUCLAIR 1975). Bartom, the broad bean cultivar preferred by Aphis fabae (SCOPOLI, 1763), was found to contain far more sugars, nitrogen, proteins and free amino acids than the less attractive Hangdom White cultivar (CicHOCKA \& LESZCZYŃSKI 2000).

Feeding requirements in aphids depend not only on the quantity, but also the quality, or even the ratio between individual ingredients found in the food matter. What is more, the requirements change with the growth and development of the given species (LESZCZYŃSKI et al. 2000). Proper growth and development of herbivores depends on proteins and amino acids. Plant cell sap contains around $0.2 \%$ protein amino acids, whereas phloem sap contains even less (KRZYWIEC 1968, SEMPRUCH 2010). The presence of particular amino acids in the plant influences fertility, growth and development of females and also plant resistance (Ciepiela et al. 2002, SEMPRUCH \& Ciepiela 2002, SPRAwKa et al. 2002, WilKINSON \& DOUGLAS 2003, SEMPRUCH \& CIEPIELA 2004). Equally important are vitamins, as well as macro- and microelements. Also vital is the presence of saponins, which are harmful to aphids (SZYNKARCZYK et al. 2001). Acyrtosiphon pisum did not develop well on burclover with a high level of these substances. Covering leaves with wax is another factor that influences the acceptability of a plant as a host (WóJCICKA et al. 2001). Cultivars of winter triticale heavily coated with wax were not widely accepted by Sitobion avenae. The number of aphids on plants is also limited by phenol compounds (CichockA et al. 2000, ChrZANOwsKi et al. 2002). Higher levels of these substances lowered the feeding preferences of $A$. fabae in the case of broad beans, and could enhance resistance of winter triticale against S. avenae (CIEPIELA et al. 2000). GolAN (2013) studied the influence of Coccus heperidum LinNaEus 1758 on three host plants - Citrus limon (LinNAEUS, 1753) BURMAN, 1768, Ficus benjamina LinNAEUS, 1767, and Nephrolepis biserrata (SWARTZ, 1800) SCHOTT, 1834. Coccus heperidum was the most abundant on 
Citrus limon, but in the free-choice test Ficus benjamina was chosen by mobile individuals of Coccus heperidum as a host plant. Leaves of Ficus benjamina contained the highest amounts of sugars and protein nitrogen, while Nephrolepis biserrata contained the highest levels of essential and non-essential amino acids.

Virus infections that induce physiological changes in wheat tissues can increase the nutritional value of plants, thus increasing the number of aphids (FERERES et al. 1990, CIEPIELA et al. 1998). Pesticides (herbicides and insecticides) that can change the quality of proteins or influence the metabolism of the host plants may aid the development of the cereal aphid population (RoOT \& SKELSEY 1969, SLOSSER 1989, CIEPIELA et al. 2001, 2004). More intense application of nitrogenous fertilizers increased the abundance of whitefly (Bemisia argentifolii BeLLOws \& PERRING, 1994) on cotton (BI et al. 2001).

\section{THE INFLUENCE OF APHID FEEDING ON PLANT GROWTH AND DEVELOPMENT}

The saliva of aphids can block the transfer of sap in sieves and that of water in vessels. Plant cells and nuclei increase in size. Around the stylets one can observe an increase in the number of cells and nucleic acid. Chloroplasts degenerate, and starch is broken down to monosaccharides. It has also been observed that the leaf blade becomes smaller and deformed. Saliva that permeates xylem causes disorders in its differentiation (CICHOCKA 1980). Moreover, aphid saliva contains viruses that can cause viral diseases in plants, including those they do not inhabit. This is possible because in order to find the right host plant winged morphs pierce numerous plants; in doing so they extract viruses and transmit them to other plants. Some aphids can transmit numerous viruses. For instance, Myzus persicae (SUlZER, 1776) transmits over 100 viruses (CICHOCKA 1980, KATIS et al. 2007).

In order to assess the harmfulness of aphids it is important to determine their impact on plant assimilation and respiration, as well as the components of the dry matter (VICKERMAN $\&$ WRATTEN 1979). The substances present in aphid saliva impact on growth and basic life processes, such as photosynthesis, respiration, transpiration and nitrogen metabolism (RABbinge et al. 1990, Kornatowska \& PiETKIEWICZ 1991, SEMPRUCH \& CiePIEla 2001, GOGGIN 2007). CICHOCKA et al. (1992) studied the influence of seven aphid species on the photosynthesis, respiration and transpiration of their host plants. They came to the conclusion that these responses depended on the aphid and plant species. After longer feeding periods the rate of photosynthesis always decreased, whereas respiration decreased in some plants and increased in others. The same was observed in relation to transpiration. As a result of aphid feeding, cereal ears receive fewer photosynthesis products, which affects the yield and quality of the plants (RABBINGE et al. 1990). The number of seeds in 
an ear and their mass were both found to decrease. The majority of the examined types of wheat showed lower levels of germination energy and force in seeds originating from plants inhabited by aphids (KoRNATOwSKA 1994). The feeding of Sitobion avenae causes an increase in nitrogen transfer into the ears, where it is extracted by aphids (JAHN \& MERBACH 1984). In the seeds of wheat infested by S. avenae the amounts of amino acids such as aspartic and glutamic acids, methionine and arginine were lower than in the control sample (ZWOLIŃSKA-ŚNIATAŁOWA et al. 1989). SPRAWKA et al. (2003) showed that the feeding of $S$. avenae on the ears of spring triticale caused a decrease in the content of essential amino acids.

Indirect harmfulness includes the excretion of large amounts of honeydew by Sternorrhyncha. This was found to contain glucose, sucrose, fructose, maltose, trehalose, mannitol, arabinose, as well as dextrins and small amounts of amino acids (WoOL et al. 2006, GOLAN \& NAJDA 2011). The amount of excreted honeydew depends on the aphid species and the quality of extracted food matter (AUCLAIR 1984). Therioaphis trifolii (MONELL, 1882) produces more honeydew on susceptible plants, than on resistant ones (CICHOCKA \& GoszCZYŃSKI 1986). Differences in the quantity of excreted honeydew and its chemical ingredients in the case of Sitobion avenae feeding on various types of winter triticale are also described by CIEPIELA \& SEMPRUCH (2000). Honeydew covers the leaves and shoots; assimilation by these organs is thus impaired, especially if saprophytic fungi develop on the honeydew. This also makes it harder for the plant to respire and can cause chlorosis and physiological changes in leaves. Leaves covered in honeydew fall early (Cichocka 1984, Rabbinge et al. 1990, Rossing \& VAN DE Wiell 1990, CichocKA 2001). Large amounts of honeydew are excreted by Eucallipterus tiliae (LINNAEUS, 1758) on lime trees in the years of its large-scale occurrence (CICHOCKA 2001, MACKOŚ-IWASZKO \& LUBIARZ 2014). Large amounts of honeydew are also excreted by Trialeurodes vaporariorum (WESTWOOD, 1856) on its host plants. However, GOSZCZYŃSKI (1988) claims that the coating of plants by honeydew is just one of the many reasons for the harmfulness of this whitefly species in greenhouse cultivation in Poland.

During spring Dysaphis crataegi (KALTENBACH, 1843) causes red protuberances on hawthorn leaves. The assimilation of these leaves was found to be weaker than that of control leaves; the chlorophyll content was lower as well (GOSZCZYŃSKI 1994). CICHOCKA (1984) reports that Pemphigus bursarius caused a threefold decrease in the intensity of photosynthesis in the leaves of cottonwood. This species decreased the mass of lettuce heads in direct proportion to the number of aphids on the plant's roots (СiCHOCKA \& GosZCZYŃSKI 1992). The dry matter content of the leaves of this lettuce also decreased, with a consequent reduction in sugars and vitamin $\mathrm{C}$, and an increase in nitrogen, protein and chlorophyll contents. The tap roots of carrots infested by Pemphigus phenax (BÖRNER \& BLUNK 1916) exhibited a decrease in reducing sugars, as well as an increase in the 
amount of proteins and $\beta$-carotene. The leaves of cottonwood that had galls of both these Pemphigus HARTIG, 1839 species, displayed the greatest decrease in chlorophyll content (CICHOCKA \& GosZCZYŃSKI 1992). Cavariella aegopodii (SCOPOLI, 1763) feeding on dill reduced the rate of photosynthesis by about $40 \%$, while simultaneously increasing the rate of respiration (СICHOCKA 1992). The feeding of Macrosiphoniella sanborni (GILLETTE, 1908) decreased the rate of photosynthesis in only some chrysanthemum cultivars, but respiration neither increased nor decreased. The chlorophyll content in some varieties was lower, some did not react to aphid feeding while in others the content was slightly higher (CiCHOCKA 1992). SYTYKIEWICZ et al. (2013) demonstrated loss of chlorophyll in maize seedlings infested by Rhopalosiphum padi (LINNAEUS, 1758) and Sitobion avenae. The feeding of Coccus heperidum caused an increase in the sugar concentration of leaves of Citris limon, Ficus benjamina and Nephrolepis biserrata, and a decrease in the contents of other primary metabolites (GOLAN 2013). GOSZCZYŃSKI $(1988,1992)$ studied the influence of Trialeurodes vaporariorum on tomatoes and cucumbers, the latter proving to be more susceptible than the former. Ingredients of whitefly saliva caused physiological changes to photosynthesis and respiration, as well as to the amounts of some substances in leaves. TOMCZYK \& GOSZCZYŃSKI (1996) observed a negative influence of Hyperomyzus lactucae (LiNNAEUS, 1758) on photosynthesis, growth and yield in blackcurrants, and there were higher amounts of reducing sugars and phenol compounds in the leaves and fruit of this plant.

Aphid feeding influences the activity of enzymes (SEMPRUCH \& CIEPIELA 2001, ChrZANOwski et al. 2003, CiEPIELA et al. 2005, SEMPruCH et al. 2009). Rhopalosiphum padi feeding increases the activity of chlorophyllase and $\mathrm{Mg}$-dechelatase in the leaves of bird cherry. In the places where aphids were numerous the leaves were discoloured yellow or light green (CIEPIELA et al. 2005). Sitobion avenae feeding induced fluctuations of tyrosine decarboxylase in the winter triticale Tornado cv. Furthermore, changes in this enzyme's activity were of a systemic character (SEMPRUCH et al. 2009). The feeding of $S$. avenae also reduced polyphenoloxidase activity in the ears of spring wheat and triticale (CHRZANOWSKI et al. 2003). SEMPRUCH et al. (2008a, 2008b) demonstrated the influence of grain aphid feeding on the activity of ornithine decarboxylase and arginase in two cultivars of winter triticale.

\section{CONCLUSIONS}

Mutual interactions between piercing-sucking insects and their host plants are a vast subject, so this paper has focused only on some of the most important issues. The manner in which aphids penetrate plant tissues, as well as the influence on host plants of the saliva 
they produce are discussed. Other issues addressed include the changes (mainly decreases) in the quality of plants infested by aphids and other representatives of the Sternorrhyncha suborder. To conclude, the most important consequences of aphid feeding include:

1. deformation of tissues, which the aphid mouthparts pierce during feeding,

2. disorders of plant metabolism:

- impaired plant growth,

- disorders in plant development, evidenced by weaker blooming, or weaker germination energy in seeds that originated from plants infested by aphids,

- decreases in the rate of photosynthesis and respiration of infested plants,

- blocked sap transfer in sieves, and water transfer in vessels,

3. by coating plant organs, the honeydew excreted by piercing-sucking insects also affects the metabolism and development of the infested plants,

4. changes (increase or decrease) in the amounts of various substances (e.g. sugars, amino acids, proteins, phenol compounds) in plant tissues caused by aphid feeding,

5. introduction of viruses with aphid saliva into plants, which can cause viral diseases in them.

Therefore, the most important consequence of aphid feeding is decreased yield quality. The feeding of piercing-sucking insects leads to dieback of entire herbaceous plants or some parts (organs) in the case of trees and shrubs. This, in turn, causes yield losses during the time when numerous colonies of aphids attack herbs as wells as cultivated and decorative plants. This also leads to financial losses.

\section{REFERENCES}

Al-Mousawi A.H., Richardson P.E., BuRTon R.L. 1983. Ultrastructural Studies of Greenbug (Hemiptera: Aphididae) Feeding Damage to Susceptible and Resistant Wheat Cultivars. Annals of the Entomological Society of America 76(6): 964-971.

AuCLAIR J.L. 1963. Aphids feeding and nutrition. Annual Review of Entomology 8(13): 439-490.

AuClair J.L. 1976. Feeding and Nutrition of the Pea Aphid Acyrthosiphon pisum (HARRIS) with Special Reference to Amino acids. [in:] T. JERMY (ed.). The Host-Plant in Relation to Insect Behaviour and Reproduction, Springer US - Akadémiai Kiadó, Budapest, 29-34.

AuClaIR J.L. 1984. Nutritional physiology of aphis biotypes. [in:] XVII International Congress of Entomology, Hamburg, Federal Republic of Germany, August 20-26, 1984. Abstract Volume. Deutsche Gesellschaft für allgemeine und angewandte Entomologie, Müncheberg, 167-169.

BARANOwSKi T. 1974. Aphids occurring on Chrysanthemums. Ochrona Roślin 6: 16-19. (in Polish)

Bi J.L., Ballmer G.R., Hendrix D.L., Henneberry T.J., Toscano N.C. 2001. Effect of cotton nitrogen fertilization on Bemisia argentifolii populations and honeydew production. Entomologia Experimentalis et Applicata 99(1): 25-36. 
Botha C.E.J., Evert R.F. 1978. Observations of preferential feeding by the aphid, Rhopalosiphum maidis on abaxcal phloem of Cucurbita maxima. Protoplasma 96(1-2): 75-80.

Carolan J.C., Fitzroy C.I.J., Ashton P.D., Douglas A.E.,, Wilkinson T.L. 2009. The secreted salivary proteome of the pea aphid Acyrthosiphon pisum characterised by mass spectrometry. Proteomics 9(9): 2457-2467.

Cherqui A., TuallingiI W. F. 2000. Salivary proteins of aphids, a pilot study on identification, separation and immunolocalisation. Journal of Insect Physiogt 46(8): 1177-1186.

Chrzanowski G. Ciepiela A.P., Sempruch C., Sprawka I., Sytykiewicz H., Czerniewicz P. 2002. Accumulation of gallic and salicylic acids in winter triticale in response to aphids attack. Herba Polonica 48(4): 257-260.

Chrzanowski G., Ciepiela A.P., Sprawka I., Sempruch C., Sytykiewicz H., Czerniewicz P. 2003. Activity of polyphenoloxidase in the ears of spring wheat and triticale infested by grain aphid (Sitobion avenae [F.]). Electronic Journal of Polish Agricultural Universities 6(2): \#04.

CichOCKA E,. GosZCZYŃSKI W. 1986. Biology of nutrition and direct harmfulness of aphids. Zeszyty Problemowe Postępów Nauk Rolniczych 329: 7-25. (in Polish)

Cichocka E. 1980. Aphids of fruit plants in Poland. PWN, Warszawa. (in Polish)

CichockA E. 1984. Annual cycles and the impact of aphids on host plants. Wydawnictwo SGGWAR, Warszawa. (in Polish)

CichocKA E. 1992. Effect of Macrosiphoniella sanborni (GILL.), Cavariella aegopodi (SCOP.) and Rhopalosiphoninus latysiphon (DAVIDS.) on host plants. Aphids and Other Homopterous Insects 3: 43-51.

CichockA E. 2001. Do aphids always damage their host plants? Aphids and Other Homopterous Insects 8: $43-54$.

Cichocka E., GoszCZYŃSKi W. 1992. Root aphids on cultivated plants in Poland. Aphids and Other Homopterous Insects 3: 3-12.

CichockA E., GoszCZyŃSKI W., CHACIŃSKA M. 1992. The effect of aphids on host plants. I. Effect on photosynthesis, respiration and transpiration. Aphids and Other Homopterous Insects 3: 59-64.

CichockA E., LeszCZYŃski B. 2000. The use of EPG Technique in assessing of susceptibility of the broad bean to black bean aphid (Aphis fabae SCOP.). Aphids and Other Homopterous Insects 7: 29-36.

CiCHOCKA E., LESZCZYŃSKI B., GosZCZYŃSKI W. 2000. Effect of phenolic compounds on acceptance of broad bean aphid, Aphis fabae (SCOP.). Aphids and Other Homopterous Insects 7: 169-176.

Ciepiela A. 1990. Biochemical determinants of antibiosis of winter wheat cultivar Saga with respect to the grain aphid (Sitobion avenae F.). Rozprawa naukowa nr 29. Wydawnictwo WSRP Siedlce, Siedlce. (in Polish)

Ciepiela A., SEMPruch C., CZERniewicz P. 2001. Relationship between the content of some protein fractions and population density of grain aphid (Sitobion avenae F.) on the winter triticale treated with Chwastox D 179 SL. Aphids and Other Homopterous Insects 8: 195-204.

Ciepiela A., Sempruch C., Wudarczyk J., Niraz S. 1991. Influence of selected amino acids and sugars on feeding and development of the grain aphid. [in:] E. CicHOCKA, W. GOSZCZYŃSKI (eds.). Aphids: their biology, harmfulness and natural enemies, PAN, Warszawa, 81-98. (in Polish) 
Ciepiela A., Sytykiewicz H., Czerniewicz P. 2005. Changes in the activity of chlorophyllase and Mg-dechelatase in bird cherry leaves induced by Rhopalosiphon padi (L) feeding. Aphids and Other Hemipterous Insects 11: 33-38.

Ciepiela A.P., ChrZanowski G., Mudel-Ogrodnik E. 2000. Accumulation of phenolic compounds in winter triticale of different resistance to grain aphid Sitobion avenae (F) (Homoptera: Aphididae). Aphids and Other Homopterous Insects 7: 195-202.

Ciepiela A.P., CZerniewicz P., Sempruch C., Sytykiewicz H. 2004. Determination of content of free amino acids in winter triticale treated with herbicide Chwastox D 179 SL. Herba Polonica 50(3/4): $85-88$.

Ciepiela A.P., Sempruch C. 1993. Changes in the content of free amino acids and soluble nitrogen in the ears of selected cultivars of winter wheat caused by grain aphid feeding. Zeszyty Naukowe WSRP w Siedlcach, Seria Nauki Przyrodnicze 34: 117-129. (in Polish)

Ciepiela A.P., Sempruch C. 2000. The chemical composition of honeydew exctered by the grain aphid feeding on winter triticale. Kieleckie Studia Biologiczne 10: 127-133. (in Polish)

Ciepiela A.P., Sempruch C., SPRAwKa I. 1998. Changes of nutritive value of ear protein of winter triticale caused by grain aphid feeding. Aphids and Other Homopterous Insects 6: 71-78.

Ciepiela A.P., Sytykiewicz H., Sempruch C., Chrzanowski G., Sprawka I., Czerniewicz P. 2002. Amino acid composition of soluble protein in bird cherry (Prunus padus L.) leaves during its spring development. Herba Polonica 48(4): 242-246.

Czerniewicz P., Sytykiewicz H., Leszczyński B., Chrzanowski G., Sempruch C., Sprawka I. 2011. Effect of host plant nitrogen compounds on spring migration of the bird cherry-oat aphid (Rhopalosiphum padi L.). Progress in Plant Protection/Postępy w Ochronie Roślin 51(1): 409-412. (in Polish)

DAY M.F., IRZYKIEWICZ H. 1954. On the Mechanism of Transmission of Non-Persistent Phytopathogenic Viruses by Aphids. Australian Journal of Biological Sciences 7(3): 251-273.

Elzinga D.A., JANDER G. 2013. The role of protein effectors in plant - aphid interactions. Current Opinion in Plant Biology 16: 451-456.

FEIR D., BECK D.S. 1961. Salivary secretions of Oncopeltus fasciatatus (Hemiptera: Lygaeidae). Annals of the Entomological Society of America 54(2): 316.

Fereres A., Shukle R.H., Araya J.E., Foster J.E. 1990. Probing and feeding behavior of Sitobion avenae (F.) (Horn., Aphididae) on three wheat cultivars infected with barley yellow dwarf virus. Journal of Applied Entomology 109(1-5): 29-36.

Giordanengo P., Brunissen L., Rusterucci C., Vincent C., van Bel A., Dinant S., Girousse C., FAUCHER M., Bonnemain J.L. 2010. Compatible plant-aphid interactions: How aphids manipulate plant responses. Comptes Rendus Biologies 333(6-7): 516-523.

GoGGIN F. L. 2007. Plant-aphid interactions: molecular and ecological perspectives. Current Opinion in Plant Biology 10(4): 399-408.

GolaN K. 2013. Interaction between host plants and Coccus hesperidum L. (Hemiptera Sternorrhyncha; Coccidae). Rozprawy Naukowe Uniwersytetu Przyrodniczego w Lublinie, 381: $1-122$. 
Golan K., NAJDA A. 2011. Differences in the sugar composition of the honeydew of polyphagous brown soft scale Coccus hesperidum (Hemiptera: Sternorrhyncha: Coccoidea) feeding on various host plants. European Journal of Entomology 108(4): 705-709.

GosZCZYŃSKI W. 1988. Biological basis of integrated control of greenhouse whitefly (Trialeurodes vaporariorum WESTW.). Wydawnictwo SGGW-AR, Warszawa. (in Polish)

GOSZCZYŃSKI W. 1992. Effect of glasshouse whitefly (Trialeurodes vaporariorum WESTW.) on host plants. Aphids and Other Homopterous Insects 3: 97-102.

GosZCZYŃSKI W. 1994. Some aspects of Dysaphis crategi (KALT.) harmfulness. Aphids and Other Homopterous Insects 4: 63-66.

Hewer A., Becker A., van Bel A.J.E. 2011 An aphid' s Odyssey - the cortical quest for the vascular bundle. The Journal of Experimental Biology 214: 3868-3879.

Hewer A., Will T. van Bel A.J.E. 2010. Plant cues for aphid navigation in vascular tissues. The Journal of Experimental Biology 213: 4030-4042.

Hogenhout S.A., Bos, J.I. 2011. Effector proteins that modulate plant - insect interactions. Current Opinion in Plant Biology, 14(4): 422-428.

JAHN B., MerbaCH W. 1984. Einfluß der Getreidelaus (Macrosiphum avenae [FABR.]) auf die Ertragbildung von Winterweizen. Tagungsberichte - Deutsche Akademie der Landwirtschaftswissenschaften zu Berlin 224: 437-441.

JaOuAnNet M., Rodriguez P.A., Thorpe P., Lenoir C.J.G., MACLeOd R., Escudero-Martinez C., Bos J.I.B. 2014. Plant immunity in plant - aphid interactions. Frontiers in Plant Science 5: 663.

Katis N.I., TsitsiPIS J.A., Stevens M., Powell G. 2007. Transmission of Plant Viruses. [in:] H.F. van EMden, R. HARRINGTON (eds). Aphids as Crop Pests. CAB International, 353-390.

Kornatowska B. 1994. Feeding of cereal aphids and the development and metabolism of selected varieties of winter wheat. PhD thesis, SGGW, Warszawa. (in Polish)

Kornatowska B., PietKiewicz S. 1991. Growth and photosynthesis of winter wheat during feeding of aphids. [in:] E. CiсHOCKA, W. GoszCZYŃSKi (eds.). Aphids: their biology, harmfulness and natural enemies, PAN, Warszawa, 53-60. (in Polish)

KRZYwiEC D. 1968. Biology of aphids. [in:] J. ACHREMOwiCZ (ed.). Course of general aphidology. PAN, Warszawa, 53-93. (in Polish)

LESZCZYŃSKI B. 1996. The practical course in the field of chemical interaction of insects - plants on the example of aphids (Aphidoidea). Wydawnictwo WSRP, Siedlce. (in Polish)

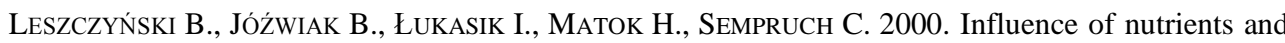
water content on host-plants alternation of bird cherry - oat aphid, Rhopalosiphum padi L. Aphids and Other Homopterous Insects 7: 223-230.

LindNER R.C., BURTS E.C., BENSON N.R. 1962. A decline condition in pears induced by pear psylla. The Plant Disease Reporter 46: 59-60.

LOWE H.J.B. 1967. Interspecific differences in the biology of aphids (Homoptera: Aphididae) on leaves of Vicia faba. I. Feeding behavior. Entomologia Experimentalis et Applicata 10(3-4): 347-357.

Mackoś-Iwaszko E., Lubiarz M. 2014. Abundance dynamics of Eucallipterus tiliae (LinNAEus 1758) on the small-leaved lime (Tilia cordata MiLL.) in the city of Lublin (South-Eastern Poland). 
[in:] P. Indykiewicz, J. BöHneR (eds.). Urban fauna. Animal, Man, and the City - Interactions and Relationships. ArtStudio, Bydgoszcz, 77-85.

Madhusudhan V.V., Miles P.W. 1998. Mobility of salivary components as a possible reason for differences in the response of alfalfa to the spotted alfalfa aphid and pea aphid. Entomologia Experimentalis et Applicata 86(1): 25-39.

MCLEAn, D.L., KinSEY, M.G. 1984. The precibarial valve and its role in the feeding behavior of the pea aphid, Acyrthosiphon pisum. Bulletin of the Entomological Society of America 30(2): 26-31.

MiLEs P.W. 1965. Studies on the salivary physiology of plant-bugs: The salivary secretions of aphids. Journal of Insect Physiology 11(9): 1261-1268.

MiLEs P.W. 1967. The physiological division of labour in the salivary glands of Oncopeltus fasciatus (DALL.) (Heteroptera: Lygaeidae). Australian Journal of Biological Sciences 20(4): 785-797.

MiLEs P.W. 1968. Insect secretions in plants. Annual Review of Phytopathology 6: 137-194.

MiLES P.W. 1987. Feeding process to Aphidoidea on their food plants. [in:] A.K. MinKS, P. HARREWIJN (eds.). Aphids Natural Enemies and Control. 2A. Elsevier, Amsterdam, 321-340.

MiLES P.W. 1999. Aphid saliva. Biological Reviews 74(1): 41-85.

MitTLER T.E. 1957. Studies on the feeding and nutrition of Tuberolachnus salignus (GMELIN) (Homoptera, Aphididae). I. The uptake of phloem sap. The Journal of Experimental Biology 34: 334-341.

Montlor C.B., TJallingiI W.F. 1989. Stylet penetration by two aphid species on susceptible and resistance lettuce. Entomologia Experimentalis et Applicata 52(2): 103-111.

Morales H., Perfecto I., Ferguson B. 2001. Traditional fertilization and its effect on corn insect populations in the Guatemalan highlands. Agriculture, Ecosystems and Environment 84(2): $145-155$.

NichOlson S.J., PUTERKA G.J. 2014. Variation in the salivary proteomes of differentially virulent greenbug (Schizaphis graminum RoNDANI) biotypes. Journal of Proteomics 105: 186-203.

Nuorteva P. 1962. Studies on the Causes of the Phytopathogenicity of Calligypona Pellucida (F.) (Hom., Araeopidae). Annales Zoologici Societatis Zoologicae-Botanicae Fennicae 'Vanamo' 23(4): $1-58$

Pollard D.G. 1971. Some aspects of plant penetration by Myzus persicae (Sulz.) nymphs (Homoptera, Apididae). Bulletin of Entomological Research 61(2): 315-324.

POLLARD D.G. 1973. Plant penetration by feeding aphids (Hemiptera, Aphidoidea): a review. Bulletin of Entomological Research 62(4): 631-714.

RABBINGE R. , ROSSING W.A.H., VAN DER WERF W. 1990. The bridge function of production ecology in pest and disease management.. [in:] R. Rabbinge, J. GoudriaAn, H. van Keulen, F.W.T. PenNing DE VRIES, H.H. LAAR (eds.). Theoretical Production Ecology: Reflection and Prospects. PUDOC, Wageningen, 181-195.

Rao S.A.K., Carolan J.C., Wilkinson T.L. 2013. Proteomic Profiling of Cereal Aphid Saliva Reveals Both Ubiquitous and Adaptive Secreted Proteins. PLoS ONE 8(2): e57413.

RodRIGUEZ P.A., Bos, J.I. 2013. Toward understanding the role of aphid effectors in plant infestation. Molecular Plant-Microbe Interactions Journal 26(1):25-30. 
Root R.B., Skelsey J.J. 1969. Biotic factors involved in crucifer aphid outbreaks following insecticides application. Journal of Economic Entomology 62(1): 223-233.

Rossing W.A.H., VAN DE WIELL A.J.M. 1990. Simulation of damage in winter wheat caused by the grain aphid Sitobion avenae. I Quantification of the effects of honeydew on gas exchange of leaves and aphid populations of different size on crop growth. Netherlands Journal of Plant Pathology 96(6): 343-364.

SCHÄLLER, G. 1963. Papierchromatographische Analyse der Aminosäuren und Amide des Speichels und Honigtaues von 10 Aphidenarten mit unterschiedlicher Phytopathogenität. Zoologische Jahrbücher. Abteilung für Allgemeine Zoologie und Physiologie der Tiere 70: 399-406.

SEMPRUCH C. 2010. The role of nitrogen compounds in the interaction between plants and herbivorous insects. Kosmos 59(1-2): 199-209. (in Polish)

Sempruch C. Ciepiela A.P. 2004. The content of free protein amino acids in selected species and cultivars of cereals versus the density of grain aphid (Sitobion avenae F.) population. Acta Scientiarum Polonorum Biologia 3(1): 61-69.

Sempruch C. WójCicka A., Makosz M., LeszczyŃski B. 2008a. Changes in activity of ornithine decarboxylase in winter triticale seedlings stressed by grain aphid attack. Zeszyty Problemowe Postępów Nauk Rolniczych 524: 401-408.

Sempruch C., Ciepiela A.P. 2001. The activity of nitrate and nitrite reductase in winter triticale infested by grain aphid (Sitobion avenae F.) Aphids and Other Homopterous Insects 8: 213-221.

Sempruch C., Ciepiela A.P. 2002. Changes in content and amino acid composition of soluble protein in winter triticale cultivars caused by grain aphid feeding. Journal of Plant Protection Research 42(1): 37-44.

Sempruch C., Leszczyński B., Wójcicka A., Makosz M., Chrzanowski G. Matok H. 2009 Changes in Activity of Triticale Tyrosine Decarboxylase Caused by Grain Aphid Feeding. Polish Journal of Environmental Studies 18(5): 901-906.

SEMPRUCH C., LESZCZYŃSKI B., WOJTAŚ I. 2008b. Activity of arginase within winter triticale seedlings attacked by grain aphid (Sitobion avenae F.). Pestycydy/Pesticides 3-4: 125-130.

Slosser J.E., PinchaK W.E., Rummel D.R. 1989. A review of now and potential factors affecting the population dynamics of the cotton aphid. Southwestern Entomologist 14(3): 302-313.

SoRIN M. 1960. Insertion of stylets of aphids plant tissues. Japanese Journal of Applied Entomology and Zoology 4(1): 38-44.

SORIN M. 1966. Physiological and morphological studies on the suction mechanism of plant juice by aphids. Bulletin of the University of Osaka Prefecture. Series B Agriculture and Biology 18: 95-137.

Sprawka I., Ciepiela A., Sempruch C., ChrZanowski G., Sytykiewicz H., CZerniewicz P. 2003. Nutritive value of soluble protein of spring triticale ears infested by the grain aphid (Sitobion avenae F.). Electronic Journal of Polish Agricultural Universities 6(2): \#03.

Sprawka I., Ciepiela A.P., Sempruch C., Chrzanowski G., Sytykiewicz H., Czerniewicz P. 2002. Amino acid composition of albumins and globulins isolated from ears of winter triticale cultivars. Herba Polonica 48(4): 252-256.

SRIVASTAVA P.N., AuClair J.L. 1975. Role of single amino acids in phagostimulation, growth and survival of Acyrthosiphon pisum. Journal of Insect Physiology 21(11): 1865-1871. 
Sytykiewicz H., Czerniewicz P., Sprawka I., Krzyżanowski R. 2013. Chlorophyll Content Of Aphid-Infested Seedling Leaves Of Fifteen Maize Genotypes. Acta Biologica Cracoviensia Seria Botanica 55(2): 51-60.

SZynkarczyK S., Leszczyński B., Oleszek W., StASZEwSKi Z. 2001. Development of pea aphid, Acyrthosiphon pisum (HARRIS) bon alfalfa lines varied saponin content. Aphid and Other Homopterous Insects 8: 121-130.

TJallingII W.F. 1978. Mechanoreceptors of the aphid labium. Entomologia Experimentalis et Applicata 24(3): 731-737.

TJALLINGII W.F. 2006. Salivary secretions by aphids interacting with proteins of phloem wound responses. Journal of Experimental Botany 57(4):739-745.

TJallingiI W.F., Hogen EsCh TH. 1993. Fine structure of aphid routes in plant tissues in correlation with EPG signals. Physiological Entomology 18(3): 317-328.

TOMCZYK A., GosZCZYŃSKi W. 1996. Effect of the currant-sowthistle aphid, Hyperomyzus lectucae (L.) on blackcurrant metabolism. Aphids and Other Homopterous Insects 5: 189-195.

URBAŃSKa A., NiRAZ S. 1990. Anatomical and biochemical aspects of cereal aphids feeding. Zeszyty Problemowe Postępów Nauk Rolniczych 392: 201-213. (in Polish)

URbańsKa A., TJallingiI W.F., DixON A.F.G., LeSZCZYNSKI B. 1998. Phenol oxidising enzymes in the grain aphid's saliva. Entomologia Experimentalis et Applicata 86(2): 197-203.

UrbańSKA A., TJALLINGII W.F., LESZCZYŃSKi B. 1994. Application of agarose-sucrose gels for investigation of aphid salivary enzymes. Aphids and Other Homopterous Insects 4: 81-87.

VICKERMAN G.P., WRATTEN S.D. 1979. The biology and pest status of cereal aphis (Hemiptera: Aphididae) in Europe: a review. Bulletin of Entomological Research 60(1): 1-32.

Wilkinson T.L., Douglas A.E. 2003. Phloem amino acids and the host plant range of the polyphagous aphid, Aphis fabae. Entomologia Experimentalis et Applicata 106(2): 103-113.

Will T., Kornemann S.R., Furch A.C.U, Tuallingi W.F., van Bel A.J.E. 2009. Aphid watery saliva counteracts sieve-tube occlusion: a universal phenomenon? The Journal of Experimental Biology 212: 3305-3312.

Will T., Steckbauer K., Hardt M., van Bel A.J.E. 2012. Aphid Gel Saliva: Sheath Structure, Protein Composition and Secretory Dependence on Stylet-Tip Milieu. PLoS ONE 7(10): e46903.

Will T., TuallingiI W.F., ThÖnnessen A., van Bel A. J. E. 2007. Molecular sabotage of plant defense by aphid saliva. Proceedings of the National Academy of Sciences of the United States of America 104(25): 10536-10541.

WILl T., VAN BEL A.J.E. 2008. Induction as well as suppression. How aphid saliva may exert opposite effects on plant defense. Plant Signaling \& Behavior 3(6): 427-430.

WiLl T., Vilcinskas A. 2015. The structural sheath protein of aphids is required for phloem feeding. Insect Biochemistry and Molecular Biology 57: 34-40.

WÓJCicka A., LESZCZYŃSKi B., SALAK-WARZECHA K. 2001. Effect of surface waxes on the grain aphid, Sitobion avenae FABR. performance on triticale cultivars. Aphids and Other Homopterous Insects 8: $281-288$. 
Wool D., Hendrix D. L., SHukry O. 2006. Seasonal variation in honeydew sugar content of galling aphids (Aphidoidea: Pemphigidae: Fordinae) feeding on Pistacia: Host ecology and aphid physiology. Basic and Applied Ecology 7: 141-151.

ZwolińSKA-Śniatalowa Z. RusZKowska M., BiLSKA W. 1989. Effect of feeding aphid on the amino acid composition of the proteins in the cereal ears. [in:] Materiały 29 Sesji Naukowej IOR. Część II - postery. PWRiL, Warszawa, 33-37. (in Polish)

Received: 3 July 2015

Accepted: 13 July 2015 